\title{
МЕЖДУНАРОДНЫЕ КОНФЛИКТЫ
}

Спиридонов В.В.

DOI: 10.7256/2305-560X.2015.1.11280

\section{ЭКОНОМИЧЕСКИЙ ПОДХОД К АНАЛИЗУ ПРИЧИН ПОЛИТИЧЕСКОГО КОНФЛИКТА В ЛИВИИ}

\begin{abstract}
Аннотация: На рубеже 2010 - 2011 г. в странах арабского мира началась волна протестов, вызванная совершенно разными, на первый взгляд, причинами, однако направленная, главным образом, против правящих элит. Так, в 2011 году в Ливии резко обострился внутриполитический кризис, осложнившийся американским и европейским военным вмешательством. Результатом противостояния в Ливии стало свержение действующей власти во главе с М. Каддафи и, как следствие, резкий экономический спад, перешедший затем в стадию распада. В настоящей статье проведён обзор и анализ факторов внутри- и внешнеэкономического развития, результатов внешнеторговой деятельности Ливии. Проведён анализ развития реального и финансового секторов экономики. Анализ указанных экономических параметров, а именно: структуры бюджета, торгового баланса, финансового состояния с точки зрения денежной структуры, соотношения иностранных и внутренних активов, резервов, векторов движения капитала Ливии позволил обнаружить взаимосвязь между их динамикой и потенциальной угрозой стабильности государства.
\end{abstract}

Ключевые слова: международные отношения, внешняя политика, США, Ливия, экономика, конфликт, Каддафи, финансы, бюджет, национальные интересы.

Л ивия государство в Северной Африке, расположено на побережье Средиземного моря. Входит в группу стран Магриба.

Площадь 1,76 млн. кв. км, 90 \% из которой занимают пустыни. Ливия является четвёртой по площади на Африканском континенте и шестнадцатой в мире. Население Ливии составляет 6,3 млн. чел. Столица - Триполи. Здесь проживают 1,7 млн. чел. Условно Ливия делится на три части: Триполитания (запад), Киренаика (восток) и Феццан (юг).

Вследствие жаркого климата, бедности почв, сельское хозяйство развито плохо. Вклад агропромышленного комплекса в валовой внутренний продукт (ВВП) крайне низок и продолжает падение. Что подтверждается следующим показателем: вклад сельскохозяйственной отрасли в ВВП составил в 2000 году $8 \%$, а в 2005 году только $2,7 \%$. При этом $75 \%$ продовольственных товаров импортируется.

Важно отметить, что несмотря на климатические условия Ливия не испытывает недостатка в пресной воде: в стране обнаружены её подземные запасы.

Ливия - это индустриальная страна с плановой экономикой. Основными отраслями промышленности являются: нефтедобывающая и нефтеперерабатывающая промышленность, добыча подземной пресной воды, пищевая, текстильная, цементная, металлургическая промышленность.
Ключевые экономические показатели Ливии представлены в таблице 1.

Таблица 1.

Ряд экономических показателей Ливийской Джамахирии за период с 2005 по 2010 г.*

\begin{tabular}{|c|c|c|c|c|c|c|}
\hline Показатель & 亡̊ & $\begin{array}{l}\dot{L} \\
\stackrel{N}{0}\end{array}$ & 亡் & $\begin{array}{l}\dot{L} \\
\stackrel{\infty}{\circ} \\
\stackrel{N}{ }\end{array}$ & ட் & 눙 \\
\hline ВВП, млрд.долл. & 44,0 & 56,5 & 71,7 & 89,9 & 59,9 & 73,2 \\
\hline из которого & & & & & & \\
\hline нефтегаз. ВВП, \% & 40 & 40 & 40 & 40 & 40 & 40 \\
\hline ненефтегаз. ВВП, \% & 60 & 60 & 60 & 60 & 60 & 60 \\
\hline ВВП, млрд.динар & 59,5 & 72,3 & 87,6 & 114,0 & 78,2 & 95,6 \\
\hline $\begin{array}{c}\text { ВВП на душу населе- } \\
\text { ния, тыс. долл. }\end{array}$ & 7,5 & 9,5 & 11,8 & 14,5 & 9,5 & 11,3 \\
\hline $\begin{array}{c}\text { Темп изменения ВВП } \\
\text { Нефтегаз. } \\
\text { Ненефегаз. }\end{array}$ & $\begin{array}{c}7,2 \\
13,6\end{array}$ & $\begin{array}{l}4,3 \\
7,9\end{array}$ & $\begin{array}{l}2,8 \\
9,9\end{array}$ & $\begin{array}{c}0 \\
8,0\end{array}$ & $\begin{array}{l}-1,5 \\
6,0\end{array}$ & $\begin{array}{l}3,7 \\
7,0\end{array}$ \\
\hline Инфляция, \% & 1 & 1,01 & 1,05 & 1,1 & 1,05 & 1,04 \\
\hline $\begin{array}{c}\text { Темпы инфляции, } \\
\text { \% в год }\end{array}$ & 2,9 & 1,4 & 5,2 & 10,4 & 5,2 & 4,5 \\
\hline
\end{tabular}

* По данным отчёта МВ $\Phi^{1}$.

1 International Monetary Fund, Socialist People's Libyan Arab Jamahiriya: 2009 Article IV Consultation-Staff Report; Public Information Notice on the Executive Board Discussion; and Statement by the Executive Director for the Socialist People's Libyan Arab Jamahiriya, September 2009 IMF Country Report No. 09/294 


\section{Международные отношения / International Relations / № 1 / 2015}

Как следует из представленной таблицы, общий объём ВВП Ливии в период с 2005 по 2010 г.г. возрастает. Вместе с этим, возрастает и ВВП на душу населения.

Структура ВВП в общем виде состоит из двух составляющих: нефтегазовая и ненефтегазовая.

Темпы роста ВВП в рассматриваемый период имеют тенденцию к снижению: несмотря на увеличение темпов роста ВВП в 2007 г. на 6\%, имеет место падение темпов роста ВВП в следующем, 2008 г., до 3,8 \%.

Как следует из представленных в таблице 1 данных, имеет место одновременный рост объёмов обеих составляющих ВВП Ливии. Сравнивая скорость роста компонент ВВП, следует отметить, что значения темпа роста ненефтегазовой составляющей ВВП, во-первых, выше таковых для нефтегазовой составляющей, во-вторых, несмотря на тенденцию к уменьшению в обоих случаях, падение темпов нефтегазовой составляющей ВВП происходит намного более выражено.

Темпы роста инфляции, как это следует из представленной таблицы 1 , невелики и составляют в среднем $4 \%$ в год.

Данные ключевых показателей государственного бюджета Ливии представлены в таблице 2.

Таблица 2.

Показатели государственного бюджета Ливийской Джамахирии за период с 2005 по 2010 г.*

\begin{tabular}{|c|c|c|c|c|c|c|}
\hline Показатель & 占 & $\begin{array}{l}\dot{L} \\
\text { ठ̊ }\end{array}$ & 홍 & 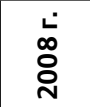 & 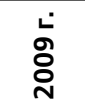 & 옹 \\
\hline $\begin{array}{c}\text { Доходы, \% ВВП } \\
\text { из которых: }\end{array}$ & 62,9 & 62,4 & 60,8 & 64,0 & 66,5 & 64,9 \\
\hline нефтегаз. & 58,7 & 57,2 & 55,5 & 58,3 & 60,6 & 49,8 \\
\hline ненефтегаз & 4,2 & 5,2 & 5,3 & 5,7 & 5,9 & 5,1 \\
\hline Расходы, \% ВВП & 33,5 & 31,0 & 35,3 & 39,3 & 55,9 & 49,1 \\
\hline Баланс, \% ВВП & 29,4 & 31,4 & 25,5 & 24,6 & 10,6 & 15,8 \\
\hline $\begin{array}{c}\text { Ненефтегазовый } \\
\text { баланс } \\
\text { из которого: } \\
\text { Ненефтегазов } \\
\text { дефицит, \% ВВП }\end{array}$ & $-29,1$ & $-26,2$ & $-29,0$ & $-32,7$ & $-42,6$ & $-37,2$ \\
\hline $\begin{array}{l}\text { Ненефтегазов. } \\
\text { дефицит, \% не- } \\
\text { нефтегазов. ВВП }\end{array}$ & $-130,4$ & $-135,3$ & $-136,0$ & $-165,8$ & $-131,6$ & $-124,6$ \\
\hline
\end{tabular}

* По данным отчёта МВ $\Phi^{2}$.

\footnotetext{
2 International Monetary Fund, Socialist People's Libyan Arab Jamahiriya: 2009 Article IV Consultation-Staff Report; Public Information Notice on the Executive Board Discussion; and Statement by the Executive Director for the Socialist People's Libyan Arab Jamahiriya, September 2009 IMF Country Report No. 09/294
}

Как следует из представленной таблицы 2, структура государственных финансов Ливии в представлена статьями: 1) доходов, 2) расходов, 3) общим балансом. Структура доходов, в свою очередь, представлена нефтегазовой и ненефтегазовой компонентами.

В период с 2005 по 2010 г. рост доходов сохраняет практически неизменное значение и составляет около 63 \% ВВП за каждый отчётный период. Рост расходов в рассматриваемый период также сохраняет неизменное значение и составляет около 20\% ВВП.

Таким образом, доходы превышают расходы, значит общий баланс Ливии период с 2005 по 2010 г. положителен. Это свидетельствует о профиците бюджета Джамахирии, который в среднем за рассматриваемый период составляет около $33 \%$ от ВВП.

Анализ и сравнение статей доходов - нефтегазовой и нененфтегазовой-заслуживает пристального внимания. Обращает на себя внимание, что ненефтегазовый баланс имеет отрицательное значение и составляет $-30 \%$ ВВП. Кроме того, сопоставление ненефтегазового баланса с той частью ВВП, которая не связана с добычей, переработкой, экспортом нефти (ненефтегазовый ВВП), отрицательное значение баланса составляет уже -130\%. Это свидетельствует о больших диспропорциях в структуре экономики Ливии и серьёзной зависимости поступлений в государственный бюджет от экспорта нефтепродуктов. В 2010 году, по данным Международного валютного фонда, более 95\% доходов от экспорта и около $80 \%$ платежей в бюджет Ливии приходится на торговлю нефтью.

Статус Ливии как экспортёра нефти можно проанализировать на основании данных по объёмам добычи нефти.

Итак, добыча нефти в Ливии началась в 1959 г.; экспорт - в 1961 г. Были созданы крупные промышленные комплексы по нефтедобыче и нефтепереработке. По данным Oil\&Gas journal и ОПЕК, Ливия имеет около 44 млрд. барр. нефтяных резервов и около 54 тлрн куб. футов запасов газа. В 2009 году общее производство нефти (нефть плюс конденсаты) составило около 1,8 млн. барр./сут. Ливийское правительство планировало увеличить нефтяные резервы, добывающие мощности, а в среднесрочной перспективе- заняться развитием газового сектора. Основными конкурентами Ливии по добыче нефти являются Нигерия (2,2 млн. барр./сут.) и Ан- 
Международные конфликты / International Conflicts

гола (1,9 млн. барр./сут.). Основными импортерами ливийской нефти являются Италия, Германия, Испания, Франция, Китай, США. Меньшие объемы импортируют также Австрия, Великобритания, Греция, Швейцария.

По данным на 2005 г., в Ливии добывали 1,69 млн. барр./сут., а в 2010 уже 1,85 млн. барр./сут. Прогноз выручки от продажи нефти составляли при условии стоимости ливийской нефти на мировом рынке от 51,9 долл./барр. в 2005 г. до 72 долл./ барр. в 2010 г.

Таким образом, несмотря на диспропорции в экономике, правительству Ливии удалось использовать весьма удачную конъюнктуру спроса-предложения на рынке энергоносителей, сложившуюся к началу 2000-х г., и значительно усилить финансово-экономические позиции в мире. Так, по результатам 2008 г. доходная часть бюджета Ливии составила 56,3 млрд. долл.; расходная около 29,1 млрд. долл. Таким образом, профицит бюджета составил 27,2 млрд. долл. Следует отметить, что доходы Ливии от экспорта нефти в указанном году составили $\$ 40$ млрд. или $71 \%$ от общей величины доходов. Колоссальный уровень доходов связан, в свою очередь, с рекордными мировыми ценами на нефть, которые в 2010 г. составили в среднем

102 долл./барр. Правительство Ливии верстало расходную часть бюджета таким образом, чтобы привязать её к цене барреля нефти в районе 50 долл., просчитывая и возможные значительные колебания мировых цен на энергоносители.

Подобная выгодная экономическая ситуация сложилась, во многом благодаря тому, что Ливийская Джамахирия, много лет блокированная от полноценной внешней торговли, пошла на уступки мировому сообществу, отказавшись, в частности, от разработки оружия массового уничтожения. В результате Ливии удалось выйти из международной изоляции, реализовать экспортный потенциал, уловить момент наибольшего благоприятствования внешней торговли, стать полноправным игроком на мировом финансовом рынке.

Появление сверхприбылей ставит задачу перед правительствами в целесообразном их использовании. Как же была решена указанная задача правительством Ливийской Джамахирии? Для ответа на этот вопрос вначале обратимся к результатам исследования денежной структуры Ливии за период с 2005 по 2010 г., приведённым в таблице 3 .
Таблица 3.

Денежная система Ливийской Джамахирии за период с 2005 по 2010 г.*

\begin{tabular}{|c|c|c|c|c|c|c|}
\hline $\begin{array}{c}\text { Показатель, } \\
\text { млн. долл. }\end{array}$ & นั่ & ட் & 홍 & $\begin{array}{l}\dot{L} \\
\stackrel{0}{0} \\
\stackrel{N}{N}\end{array}$ & ட். & 올 \\
\hline $\begin{array}{c}\text { Чистые ино- } \\
\text { странные } \\
\text { активы }\end{array}$ & 56.422 & 79.434 & 100.744 & 124.830 & 138.410 & 154.845 \\
\hline $\begin{array}{c}\text { Чистые вну- } \\
\text { тренние активы }\end{array}$ & -40.948 & -61.490 & -75.604 & $\mid-87.679$ & -96.057 & -104.869 \\
\hline $\begin{array}{c}\text { Внутренний } \\
\text { кредит, } \\
\text { из которого }\end{array}$ & -26.611 & -47.148 & -58.414 & -69.328 & -81.152 & -93.976 \\
\hline $\begin{array}{l}\text { Кредит прави- } \\
\text { тельству, }\end{array}$ & -35.459 & -57.048 & -69.719 & -82.044 & -95.610 & -110.687 \\
\hline $\begin{array}{c}\text { Темпы измене- } \\
\text { ния, \% в год }\end{array}$ & -97 & -61 & -22 & -18 & -17 & -16 \\
\hline & 8.848 & 9.871 & 11.305 & 12.716 & 14.458 & 16.711 \\
\hline $\begin{array}{c}\text { Темпы измене- } \\
\text { ния, \% в год }\end{array}$ & 7,7 & 11,5 & 14,5 & 11,5 & 13,7 & 15,6 \\
\hline $\begin{array}{c}\text { Широкие } \\
\text { деньги }\end{array}$ & 15.475 & 17.943 & 25.140 & 37.151 & 42.353 & 749.976 \\
\hline $\begin{array}{c}\text { Курс } \\
\text { Динар/ } \\
\text { Доллар США }\end{array}$ & 1,35 & 1,28 & 1,22 & 1,31 & - & - \\
\hline
\end{tabular}

* По данным отчёта $М B \Phi^{3}$.

Как следует из представленной таблицы, структура денежной системы Ливии представлена тремя компонентами: 1) Чистые иностранные активы; 2) Чистые внутренние активы; 3) Широкие деньги.

В течение исследуемого периода величина чистых иностранных активов Ливии положительна, их объём составляет 56.422 млн. долл. в 2005 г. и 154.845 млн. долл. в 2010 г.

Величина чистых внутренних активов отрицательна, их объём составляет -40.948 млн. долл. в 2005 г. и -104.869 млн. долл. в 2010 г.

Структура чистых внутренних активов представлена, в основном, внутренним кредитом. В свою очередь, структура внутреннего кредита представлена обязательствами правительства и требованиями на развитие экономики.

Как следует из представленных результатов, величина внутреннего кредита отрицательна, его объём составляет -26.611 млн. долл. в 2005 г. и -93.976 млн. долл. в 2010 г.

\footnotetext{
3 International Monetary Fund, Socialist People's Libyan Arab Jamahiriya: 2009 Article IV Consultation-Staff Report; Public Information Notice on the Executive Board Discussion; and Statement by the Executive Director for the Socialist People's Libyan Arab Jamahiriya, September 2009 IMF Country Report No. 09/294
} 
Правительственные обязательства в структуре внутреннего кредита составляют 35.429 млн. долл. в 2005 г. и 110.687 млн. долл. в 2010 г. Вместе с тем, требования на развитие экономики в структуре внутреннего кредита составляют 8.848 млн. долл. в 2005 г. и 16.711 млн. долл. в 2010 г.

Широкие деньги по своему объёму составляли 15.475 млн. долл. в 2005 г. и 49.976 млн. долл. в 2010 г.

Деньги в обращении, входящие в структуру широких денег составляли 3.309 млн. долл. в 2005 г. и 7.874 млн. долл. в 2010 г.

По прогнозам аналитиков МВФ, в течение 2005-2010 г. наблюдается значительное увеличение денежной базы с 10 \% до 48 \% в год, планируется уменьшение роста денежной базы до 18 \% в год.

Таким образом, правительство Ливии непрерывно увеличивало требования к иностранным государствам. Это ярко отражено интенсивным наращиванием объёма чистых иностранных активов. Вместе с тем, правительство Ливии непрерывно увеличивало и свои внутренние обязательства, компенсируя рост денежной базы в стране и подавляя инфляцию.

Для оценки вектора движения Ливийского капитала необходим более детальный анализ денежно-кредитной политики Ливии. Результаты исследования приведены в таблице 4 .

Таблица 4.

\section{Платёжный баланс Ливийской Джамахирии} за период с 2005 по 2010 г.*

\begin{tabular}{|c|c|c|c|c|c|c|}
\hline Показатель & 2005 г. & 2006 r. & 2007 г. & 2008 r. & 2009 г. & 2010 г. \\
\hline $\begin{array}{c}\text { Счёт текущих } \\
\text { операций, } \\
\text { млн.долл. } \\
\text { Экспорт } \\
\text { Импорт } \\
\text { Входящие пла- } \\
\text { тежи, млн.долл }\end{array}$ & $\begin{array}{c}17.119 \\
31.358 \\
-11.183 \\
-281\end{array}$ & $\begin{array}{c}25.179 \\
39.187 \\
-13.062 \\
1.075\end{array}$ & $\begin{array}{c}29.144 \\
29.269 \\
-17.701 \\
2.267\end{array}$ & $\begin{array}{c}36.601 \\
40.292 \\
-21.658 \\
365\end{array}$ & $\begin{array}{c}10.037 \\
14.512 \\
-22.957 \\
-375\end{array}$ & $\begin{array}{c}17.219 \\
22.571 \\
24.794 \\
-865\end{array}$ \\
\hline $\begin{array}{c}\text { Счёт движения } \\
\text { капитала, } \\
\text { млн.долл. }\end{array}$ & 21 & -4.992 & -9.554 & -21.039 & -4.735 & -5.128 \\
\hline $\begin{array}{c}\text { Ошибки и про- } \\
\text { пуски, млн.долл. }\end{array}$ & -3.377 & -348 & 596 & 1.269 & 0 & 0 \\
\hline $\begin{array}{c}\text { Общий баланс, } \\
\text { млн.долл. }\end{array}$ & 13.764 & 19.839 & 20.187 & 16.831 & 5.301 & 12.090 \\
\hline
\end{tabular}

* По данным отчёта МВФ4.

Как следует из таблицы, структура платёжного баланса представлена статьями 1) Текущий счёт; 2) Счёт движения капитала; 3) Ошибки и пропуски.

4 International Monetary Fund, Socialist People's Libyan Arab Jamahiriya: 2009 Article IV Consultation-Staff Report; Public Information Notice on the Executive Board Discussion; and Statement by the Executive Director for the Socialist People's Libyan Arab Jamahiriya, September 2009 IMF Country Report No. 09/294
Из представленной таблицы видно, структура текущего счёта представлена статьями экспорта и импорта. В период с 2005 - 2010 г. как экспорт, так и импорт возрастают. Объём экспорта значительно превосходит объём импорта. Общий платёжный баланс является активным и имеет выраженную тенденцию к росту как по объёму, так и по темпу роста.

Как следует из представленных результатов, сальдо текущего счёта в течение исследуемого периода интенсивно увеличивается.

Особого внимания заслуживает статья «Счёт движения капитала». Все международные сделки с активами (за исключением официальных валютных резервов, принадлежащих Центральному банку) выделены именно в счёт движения капитала.

Как следует из таблицы, динамика изменения сальдо счёта движения капитала в 2006 г. составила -4,992 млн. долл., а в 2008 г. -21.039 млн. долл.

Таким образом, в 2008 г. произошло довольно резкое увеличение отрицательного сальдо счёта движения капитала. Именно в этом году, по сравнению с 2006 и 2007 г., рассматриваемая величина увеличила своё отрицательное значение в 4 раза. Отрицательное сальдо счёта движения капитала определяется как чистый отток капитала из страны, когда расходы на покупку активов за границей превосходят доходы от их продажи за рубеж.

Таким образом, на основании обнаруженных результатов и по данным более ранних исследований, в предшествующие периоды и на протяжении практически всего исследуемого периода Ливия являлась крупным поставщиком капитала на международном рынке.

Анализ вектора движения Ливийского капитала представлен в таблице 5 .

В таблице 5 детально рассмотрен такой показатель, как структура иностранных активов Ливии.

Структура иностранных активов Ливии представлена следующими статьями: 1) Активы Инвестиционного Правительственного Фонда Ливии (Госинвестфонд или Libyan Investment AuthorityLIA ); 2) Чистые иностранные активы (ЧИА) на счетах Центрального Банка (ЦБ) Ливии.

В свою очередь, структура ЧИА включает в себя: а) правительственные активы; b) Чистые иностранные резервы, которые в таблице обозначены как «Резервы».

Объём иностранных активов Ливии в исследуемый период увеличивался огромными темпами. Так, в 2005 г. их объём составил 54,3 млрд. долл., а в 2010 году- уже 166 млрд. Объём чистых иностранных активов и, соответственно, резервов также увеличи- 


\section{Международные конфликты / International Conflicts}

вался. Однако доля резервов в чистых иностранных активах резко и непрерывно уменьшалась.

Таблица 5.

\section{Результаты денежно-кредитной политики Ливийской Джамахирии за период c 2005 по 2010 г.*}

\begin{tabular}{|c|c|c|c|c|c|c|}
\hline $\begin{array}{c}\text { Показатель, } \\
\text { млрд. долл. }\end{array}$ & $\mathbf{2 0 0 5}$ г. & $\mathbf{2 0 0 6}$ г. & $\mathbf{2 0 0 7}$ г. & $\mathbf{2 0 0 8}$ г. & $\mathbf{2 0 0 9}$ г. & $\mathbf{2 0 1 0}$ г. \\
\hline $\begin{array}{c}\text { Общие ино- } \\
\text { странные акти- } \\
\text { Вы, из них }\end{array}$ & 54,3 & 74,8 & 98,3 & 136,1 & 147,4 & 166,1 \\
Госинвестфонд \\
ЧИА, из них: & 40,3 & 60,0 & 80,3 & 97,1 & 102,4 & 114,5 \\
- & 38,4 & 52,7 & 48,5 & 49,4 & 53,4 & 57,6 \\
& 1,9 & 7,4 & 31,8 & 47,2 & 49,1 & 56,9 \\
\hline
\end{tabular}

* По данным отчёта МВ $\Phi^{5}$.

Итак, если резервы являются безрисковыми активами, тогда пусть все остальные активы - содержат риск, являются рисковыми. Зависимость доли рисковых активов в структуре иностранных активов Ливии с 2005 по 2010 г. представлена на рисунке 1.

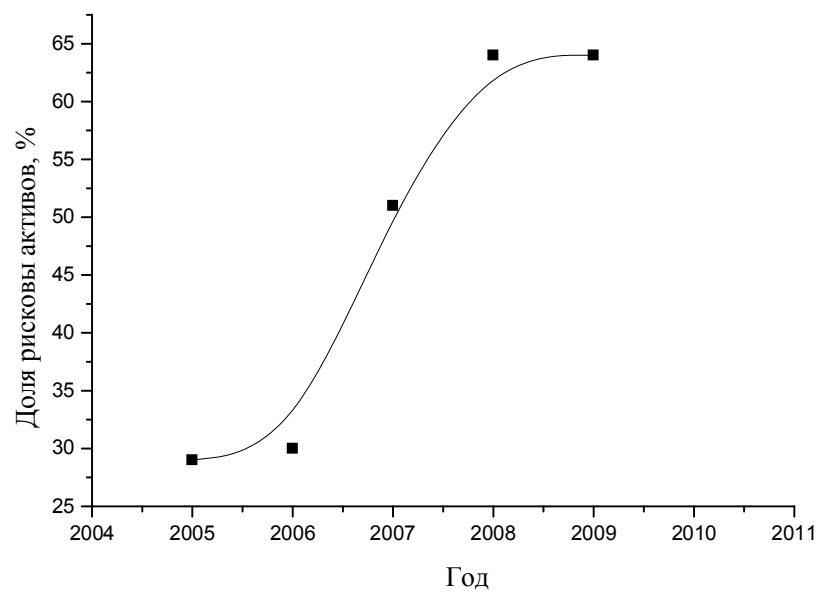

Рисунок 1. График зависимости доли рисковых активов с 2005 по 2010 г.

Как следует из рисунка 1, в течение 2005 по 2010 г. доля рисковых активов Ливии значительно увеличилась. Важно отметить, что уровень рисковых активов превысил $50 \%$ и достиг отметки в $70 \%$.

Скорость накопления рисковых активов представлена на рисунке 2.

\footnotetext{
5 International Monetary Fund, Socialist People's Libyan Arab Jamahiriya: 2009 Article IV Consultation-Staff Report; Public Information Notice on the Executive Board Discussion; and Statement by the Executive Director for the Socialist People's Libyan Arab Jamahiriya, September 2009 IMF Country Report No. 09/294
}

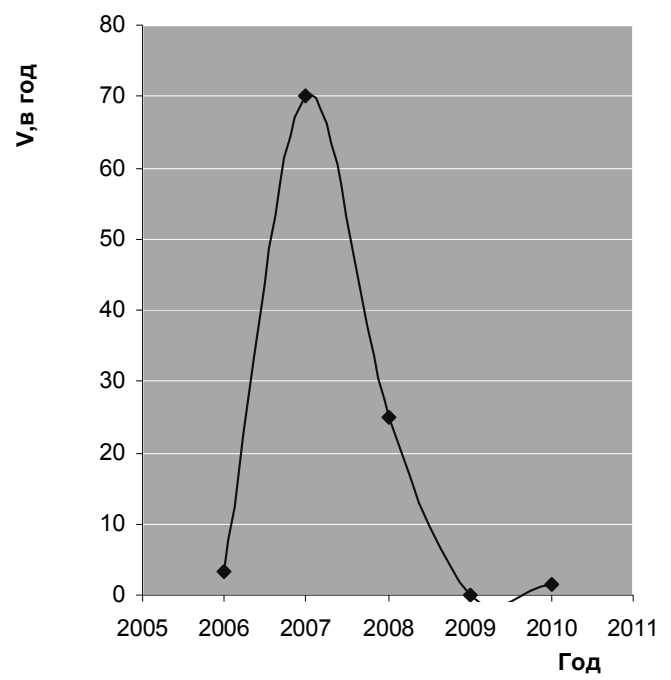

Рисунок 2. График зависимости скорости накопления рисковых активов (\% в год) с 2005 по 2010 г.

Как следует из рисунка 2, наибольшая активность в приобретении рисковых активов приходится на 2007 г. Это может означать смену инвестиционной парадигмы Ливии с умеренно-консервативной на агрессивную. Данное предположение подтверждается и предыдущим рисунком: именно на 2007 г. приходится переход 50\% уровня рисковых активов в структуре иностранных активов Ливии.

Итак, под рисковыми активами будем понимать ценные бумаги, дающие право управления, например, акции. Безрисковые активы - золотовалютные резервы - не дают права управления, но в случае внешних шоков максимально ограждают государство от экономических потрясений. Таким образом, под сменой инвестиционной парадигмы будем понимать смену целей инвестирования: от сохранения капитала до его участия в мировой финансовой политике и усиления позиций на мировом финансовом рынке не только в качестве рядового участника, но и потенциального законодателя.

На основании проведённого исследования, финансовая политика Ливии была направлена на усиление влияния на международной финансовой арене. Вместе с тем, подобная экспансия сопряжена с колоссальными рисками. Данные риски многократно увеличились, поскольку 2008 г. стал началом крупного финансового кризиса, а именно в это время ливийское правительство приняло решение, как это видно из отчёта $М В \Phi^{6}$, о самых крупных

6 International Monetary Fund, Socialist People's Libyan Arab Jamahiriya: 2009 Article IV Consultation-Staff Report; Public Information Notice on the Executive Board Discussion; and 
иностранных инвестициях, подвергнув угрозе невозврата капитал за границей.

Что же подразумевали иностранные инвестиции ливийского правительства? Ответом на этот вопрос может стать обзор лишь части материалов финансово-экономической прессы за 2008 - 2010 годы.

По данным порталов polpred.com и rusarabbc. coт от 8 июля 2009 № 187180,

правительство Ливии потеряло 500 млн.долл., инвестированных в фонд Аллена Стэнфорда7. Этот финансист обвинялся в нанесении материального ущерба своим клиентам на сумму 7 млрд.долл. вследствие махинаций по схеме Понци. На момент вложения денег в компанию Стэнфорда правительство Ливии было в полной мере осведомлено о положении дел фонда. Аллен Стэнфорд, глава американской финансовой группы Stanford Financial, совершил визит в Триполи, для встречи с чиновниками департамента инвестиционной политики Ливии. Двухдневная поездка в Триполи последовала за рядом встреч Стэнфорда и доктора Абдулхафида Злитни- секретаря по планированию правительства Ливии. Д-р Злитни, активно занимающийся развитием туризма в Ливии, также был заинтересован в осуществлении крупных инвестиций в дело Стэнфорда. Однако все личные счета Аллена Стэнфорда были арестованы, а счета Stanford Financial- заморожены, средства ливийской стороны, таким образом, возвращены не были.

Другим эпизодом инвестиционной деятельности ливийского правительства стало взаимодействие с финансовыми институтами из Европы. Так, в начале 2008 г. один из крупных европейских банков предложил суверенному инвестиционному фонду Ливии (LIA) структурный продукт на 1 млрд. евро на собственные акции. К середине 2010 г. эта инвестиция потеряла почти 72\%.

О том, что ливийский фонд Libyan Investment Authority (LIA), активы которого составляют 65 млрд. долл., понес огромные потери по сделкам с западными банками, сообщил портал ria.ru от 26 сентября 2011 № 409471. Так, группа крупных американских и европейских банков и хедж-фондов, включая организовали для LIA сделки на млрд. долл., некоторые из которых обернулись огромными убытками. В частности, предложенные опционы на корзину валют и акции ряда западных компаний принесли фонду 98\% убытка при инвестиции 1,3 млрд. долл.

Statement by the Executive Director for the Socialist People's Libyan Arab Jamahiriya, September 2009 IMF Country Report No. 09/294

Информационный портал rusarabbc.com от 8 июля 2009 № 187180
Журналисты Financial Times представили документы по сделке LIA с одним из крупнейших европейских банков. Ливийский фонд произвел инвестицию в размере 1 млрд. долл. в начале марта 2008 г. - вскоре после того, как упомянутый банк потерял 5 млрд. евро в результате действий своего трейдера, который открыл несанкционированные позиции на 50 млрд. евро. В результате банку срочно требовалось восстановить репутацию и залатать брешь в балансе, поэтому банкиры предложили LIA HOTУ с погашением в 2018 г., которая фактически должна была отражать динамику акций самого банка. По словам банкиров, фонду, как долларовому инвестору, было лучше вложиться в этот продукт, чем напрямую в акции, чтобы исключить влияние валютного курса. Кроме того, руководство этого банка представило документ, в котором сообщалось, что ошибка трейдера и последовавший за ним обвал котировок акций кредитной организации, являются возможностью купить ценные бумаги этого банка по низкой цене. В документе также сообщалось, что данный банк является потенциальным объектом для поглощения. В этой связи его акции сильно недооценены. «Более того, новости и ожидания аналитиков подогреваются слухами о $M \& A »,-$ говорится документе. В результате было подписано соглашение о покупке крупного пакета акций этого банка. Оно подписано Мухаммедом Лайасом и Мустафой Зарти- исполнительным директором LIA и его заместителем, соответственно.

По данным газеты «Ведомости» ${ }^{8}$, на начальном этапе кризиса многие западные банки, стремились привлечь богатых инвесторов из развивающихся стран, включая суверенные инвестиционные фонды, чтобы пополнить капитал. Многие из таких сделок прошли в конце 2007 г. начале 2008 г. Но затем кризис обострился, акции банков катастрофически упали.

Как сообщил источник в газете «Ведомости», американский финансовый регулятор расследует возможные случаи нарушения законов США банками, заключавшими контракты с ливийским инвестиционным госфондом. По дополнительным данным «The Wall Street Journal», Комиссия по ценным бумагам и рынкам США сейчас изучает документы, касающиеся отношений американских банков с ливийским фондом Libyan Investment Authority. Комиссия также интересуется компенсацией, которую один из крупных американских банков изначально планировал выплатить ли-

8 Информационный портал Vedomosti.ru 
вийскому фонду. Но переговоры о выплате денег были сорваны из-за начала беспорядков в Ливии. Главным итогом инвестиционной политики Ливии стало падение добычи в стране к 2013 г. до уровня 150 тысяч баррелей в день при необходимости добывать хотя бы 400 тысяч баррелей в день, для того чтобы выплачивать зарплату служащим госсектора. Правительство начало использовать денежные резервы. Однако их не хватит надолго. Если ситуация с добычей и экспортом нефти не улучшится, к концу 2013 г. - началу 2014 г. обязательства по оплате госслужащим выполнены не будут.

Анализ экономического развития Ливии с 2005 по 2010 г. позволил выявить следующие закономерности.

Во-первых, в течение исследуемого периода имел место рост как ВВП, так и ВВП на душу населения. Это, очевидно, свидетельствует как об экономическом росте, так и росте благосостояния населения. Это означает, в свою очередь, что социально-экономических предпосылок политического кризиса в Ливии к 2010 - 2011 г. не было.

Во-вторых, структура ВВП доходов, экспорта, импорта имеет диспропорции: велико влияние нефтегазового сектора. Несмотря на это, внешнеторговые отношения с иностранными государствами были выстроены таким образом, что недостаток товаров был полностью покрыт импортом. Благоприятная конъюнктура, сложившаяся на рынке энергоносителей, способствовала увеличению экспорта нефти и газа из Ливии, увеличению товарообмена между Джамахирией и иностранными государствами, а также накоплению финансово-ресурсной базы. С другой стороны, зависимость товарообмена между Ливией и остальным миром от политической и экономической конъюнктуры ставит под угрозу, например, оборонную и продовольственную безопасность государства.

Тем не менее, в 2004 г. правительство Ливии пошло на уступки мировому сообществу, отказавшись от создания на своей территории оружия массового поражения. Это послужил колоссальным стимулом к отмене санкций против Ливии и укреплению международного торгово-экономического сотрудничества с Джамахирией. Таким образом, серьёзной внешнеполитической угрозы в мире Ливия не представляла.

В-третьих, по мере увеличения доходов от экспорта нефти и газа, Ливия становилась всё более заметным и влиятельным игроком на финансовом рынке. Ливийское правительство интенсивно накапливало резервы, занималось инвестициями, диверсифицировало инвестиционный портфель, создавая и вовлекая в инвестиционную деятельность финан- совые институты, например, банки и государственный инвестфонд (LIA). Ключевую роль в инвестиционном портфеле Ливии играли международные активы: в виде золотовалютных резервов и в виде инструментов, дающих право управления, например, акций. В 2007 г., как обнаружено в данном исследовании, Ливия изменила инвестиционную парадигму: с консервативной, позволяющей сохранить ресурсы и использовать их для предотвращения последствий от острых глобальных шоков, на агрессивную, направленную на усиление влияния на мировом финансовом рынке путём участия в капитале крупных транснациональных банков и корпораций.

Вместе с тем, уже в 2007 г., по-видимому, начал набирать обороты мировой финансовый кризис. Развитие мировой финансовой системы пошло на спад, увеличивая риски участников системы. Именно в это время, на смене тренда с роста на спад развития мировых финансов, правительство Ливии принимает решение об увеличении доли рисковых активов в структуре иностранных активов, подвергнув вложенный капитал колоссальной и непредсказуемой угрозе невозврата.

Партнёрами Ливии по инвестиционной деятельности были крупные финансовые институты США и Европы. Обострение кризиса 2008 - 2009 г. привело к тому, что ответить по своим обязательствам по отношению к Ливии они, очевидно, не смогли. Резкая дестабилизация внутриполитической обстановки в 2010 - 2011 г. привела к военному вмешательству сил НАТО в Джамахирию. Эти факторы полностью дестабилизировали экономическую ситуацию в Ливии, в том числе, привели к существенному уменьшению добычи нефти - основного источника доходов государства.

Дестабилизация экономической и политической обстановки, в свою очередь, привели к тому, что инвестиционные партнёры Ливии окончательно отказались от выполнения своих финансовых обязательств.

P.S. Во время написания статьи автор обратил внимание на следующие события: 22 февраля 2011 2. действующий на тот момент времени глава Ливийского государства М. Каддафи обратился к гражданам Джамахирии и мировому сообществу с обращением, в котором утверждал, что власть в стране пытаются захватить бандиты и он будет бороться с ними, используя все свои возможности и силы.

22 февраля 2014 г. с подобным обращением уже кукраинскому народу выступил глава Украины.

За несколько дней до указанных телеобращений как в Ливии, так и на Украине резко дестабилизировалась внутриполитическая обстановка. 


\section{Международные отношения / International Relations / № 1 / 2015}

\section{Библиография:}

1. International Monetary Fund, Socialist People's Libyan Arab Jamahiriya: 2009 Article IV Consultation-Staff Report; Public Information Notice on the Executive Board Discussion; and Statement by the Executive Director for the Socialist People's Libyan Arab Jamahiriya, September 2009 IMF Country Report No. 09/294

2. Информационный портал rusarabbc.com от 8 июля 2009 № 187180

3. Информационный портал www.ft.com от 30 авг. 2011 г.

4. Информационный портал Vedomosti.ru

5. Информационный портал http://online.wsj.com/

6. Информационный портал www.ogj.com/

7. Манойло А.В. Специфика цветных революций «арабской весны». // Известия Уральск. Федерального Ун-та. Сер. 3. Общественные науки. 2013. №3. С. 30-36

8. А. В. Манойло Сценарий гибели Каддафи - очередной пример использования «демократического шаблона» // Национальная безопасность / nota bene.-2012.-1.-С. 75-76.

9. Манойло А.В. Сирия и Иран в политике США: ливийский сценарий повторяется // Международные отношения.2013.-1.-C. 4-12. DOI: 10.7256/2305-560Х.2013.01.1.

10. Перов Е.В. Теория и анализ социальной конфликтогенности общества // NB: Национальная безопасность.-2013.5.-C. 67-141. DOI: 10.7256/2306-0417.2013.5.2308. URL: http://www.e-notabene.ru/nb/article_2308.html

11. А. В. Манойло Сценарий гибели Каддафи - очередной пример использования «демократического шаблона» // Национальная безопасность / nota bene.-2012.-1.-С. 75-76.

12. Карпович О.Г. Современные концепции и модели управления международными конфликтами (сравнительный политологический анализ) // Национальная безопасность / nota bene.-2013.-4.-C. 605-612. DOI: 10.7256/20738560.2013.4.6434.

13. Карпович О.Г. Проблемы и перспективы исследования современных концепций, моделей и технологий управления международными конфликтами // Национальная безопасность / nota bene.-2013.-5.-C. 80-93. DOI: 10.7256/2073-8560.2013.5.6432.

14. Г. В. Лукьянов. Ливийско-суданские взаимоотношения в 1969-1989 годах. // Исторический журнал: научные исследования.-2012.-№ 5.-С. 75-84.

15. Е. А. Виноградова. Ливия и страны Латинской Америки: информационное противоборство с Западом. // Международные отношения.-2012.-№ 1.-С. 100-105.

\section{References (transliterated):}

1. International Monetary Fund, Socialist People's Libyan Arab Jamahiriya: 2009 Article IV Consultation-Staff Report; Public Information Notice on the Executive Board Discussion; and Statement by the Executive Director for the Socialist People's Libyan Arab Jamahiriya, September 2009 IMF Country Report No. 09/294

2. Informatsionnyi portal rusarabbc.com ot 8 iyulya 2009 № 187180

3. Informatsionnyi portal www.ft.com ot 30 avg. $2011 \mathrm{~g}$.

4. Informatsionnyi portal Vedomosti.ru

5. Informatsionnyi portal http://online.wsj.com/

6. Informatsionnyi portal www.ogj.com/

7. Manoilo A.V. Spetsifika tsvetnykh revolyutsii «arabskoi vesny». // Izvestiya Ural'sk. Federal'nogo Un-ta. Ser. 3. Obshchestvennye nauki. 2013. №3. S. 30-36

8. A.V. Manoilo Stsenarii gibeli Kaddafi-ocherednoi primer ispol'zovaniya «demokraticheskogo shablona» // Natsional'naya bezopasnost' / nota bene.-2012.-1.-C. 75-76.

9. Manoilo A.V. Siriya i Iran v politike SShA: liviiskii stsenarii povtoryaetsya // Mezhdunarodnye otnosheniya.-2013.-1.-C. 4-12. DOI: 10.7256/2305-560Kh.2013.01.1.

10. Perov E.V. Teoriya i analiz sotsial'noi konfliktogennosti obshchestva // NB: Natsional'naya bezopasnost'.-2013.-5.-C. 67141. DOI: 10.7256/2306-0417.2013.5.2308. URL: http://www.e-notabene.ru/nb/article_2308.html

11. A.V. Manoilo Stsenarii gibeli Kaddafi - ocherednoi primer ispol'zovaniya «demokraticheskogo shablona» // Natsional'naya bezopasnost' / nota bene.-2012.-1.-C. 75-76.

12. Karpovich O.G. Sovremennye kontseptsii i modeli upravleniya mezhdunarodnymi konfliktami (sravnitel'nyi politologicheskii analiz) // Natsional'naya bezopasnost' / nota bene.-2013.-4.-C. 605-612. D0I: 10.7256/20738560.2013.4.6434.

13. Karpovich O.G. Problemy i perspektivy issledovaniya sovremennykh kontseptsii, modelei i tekhnologii upravleniya mezhdunarodnymi konfliktami // Natsional'naya bezopasnost' / nota bene.-2013.-5.-C. 80-93. DOI: 10.7256/20738560.2013.5.6432.

14. G. V. Luk'yanov. Liviisko-sudanskie vzaimootnosheniya v 1969-1989 godakh. // Istoricheskii zhurnal: nauchnye issledovaniya.-2012.-№ 5.-C. 75-84.

15. E. A. Vinogradova. Liviya i strany Latinskoi Ameriki: informatsionnoe protivoborstvo s Zapadom. // Mezhdunarodnye otnosheniya.-2012.-№ 1.-C. 100-105. 